\title{
The Latent Precariousness of Migrant Workers: a Study of Ukrainians Legally Employed in Poland
}

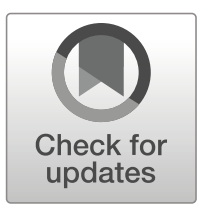

\section{Kamil Filipek $^{1}$ (D) Dominika Polkowska ${ }^{2}$}

Published online: 16 September 2019

(C) The Author(s) 2019

\begin{abstract}
The global rise in migration has captured academic attention and spurred discussions around migrants - their living and working conditions, status, relations with the host community, future plans, etc. A significant stream of research explores migrants' problems using the concept of precariousness. However, such research often becomes complicated as arrivals do not fit the frame of precariousness characterising the host society. Migrants encounter numerous problems, such as access to benefits and pensions, minimal wages, work permits or security and safety, but they do not complain or assess their personal situation as precarious. Based on fifteen in-depth interviews with Ukrainians working in Poland, this paper presents and discusses the problem of latent precariousness as a challenge to such qualitative methods as the in-depth interview. Social comparison theory has been used to explain critical problems related to the extent of precariousness among migrants.
\end{abstract}

Keywords Precariat · Ukrainians · Poland · Labour market

\section{Introduction}

Digital revolution coupled with affordable transportation reshape the structure of the global labour market towards stronger dependence on unskilled and highly skilled migrant workers (Carling, 2002; Carling and Schewel, 2018; Castells 2000; Czaika and Parsons 2017; European Migration Network 2007). Although this process has been

Kamil Filipek

kfilipek@umcs.pl

Dominika Polkowska

dominika.polkowska@umcs.pl

1 Department of Economic and Organizational Sociology, Maria Curie-Skłodowska University, Plac Marii Currie-Słodowskiej 4, 20-031 Lublin, Poland

2 Department of Economic and Organizational Sociology, Maria Curie-Skłodowska University, Lublin, Poland 
identified in such countries as the USA, Britain, Germany or France, transformation of the labour market has recently been the case also in other parts of world (e.g. Central and Eastern Europe). Castells (2000) points out three drivers stimulating global demand for international workforce: (i) employment in multinational corporations, (ii) international trade and (iii) flexible management resulting from global competition. He stresses information and communication technology as a critical factor enabling and intensifying the impact of the three drivers: "Information technology is the indispensable medium for the linkages between different segments of the labour force across national boundaries", he suggests (Castells 2000, p. 251). However, many scholars identify climate changes as a stimulus of recent international migrations (Carling and Collins 2018). Missirian and Schlenker (2017) estimate that the number of migrants seeking refuge in Europe will triple by the end of the century. Efforts to control global warming may only decrease the number of migrants but the direction of the flow will not be reversed. It is therefore hardly surprising that the rise of international migrations and its impact on the labour market is considered to be one of key challenges of our times.

The global financial crisis of 2008 confirmed that migrants are the first to lose their jobs when economic turbulences occur. Research suggests that migrants usually work long hours, receive lower pay, have no access to benefits and are often human trafficking victims in the host country (Drinkwater et al. 2009; Lewis et al. 2015). As a result, many of those deprived of basic human rights, such as freedom, social security or the right to rest, are vulnerable to modern forms of slavery and human exploitation (prostitution, organ trafficking, etc.). Moreover, many migrant workers have undocumented status in the host country with no or little chance to get a work permit. Undocumented migrants are condemned to taking the jobs nobody else wants due to difficult working conditions (e.g. on farms, in restaurants). Building on Standing's (2011) proposal, it is apparent that both documented and undocumented migrants plunge into precariousness and become members of the precariat, a new social class defined by the persistent experience of unpredictability and insecurity. Such experience prevails in contemporary economic systems built upon the pillars of globalisation and liberalisation (Hewison and Kalleberg 2013), and has an impact on migrant workers (both documented and undocumented) and their adaptation to specific socioeconomic conditions in a host country (Lewis et al. 2015).

Although multiple factors stimulate the rise of a global precarious class, many migrants do not perceive themselves or assess their position in terms of exploitation, impairment, discrimination, uncertainty and instability. Despite their often terrible living and working conditions, they tend to see themselves as winners rather than losers (a precarious class). Based on fifteen in-depth interviews with Ukrainians working in Poland conducted between February and April 2018, this essay tries to explain factors behind their positive assessment of their often difficult living and working conditions. In order to discuss the phenomena of apparent contentment and latent precariousness among the interviewees, we turn to the social comparison theory (Arrowood and Friend 1969; Festinger 1954; Wills 1981; Wood 1989). Building on this framework, we present how different points of reference may influence personal opinions and assessments and blur the factual picture of precariousness among Ukrainian workers in Poland. We also present some suggestions on how to overcome those methodological problems by adjusting the scenario of in-depth interviews to specific cultural context in which migrant research is conducted. 


\section{The Vague Concept of Precarity}

Neilson and Rossiter (2009) suggest that precariousness emerged as a political concept that describes "a series of social struggles that would spread across the space of Europe". Those struggles are not new but precariousness gained extreme popularity with the rise of social movements such as the Critical Mass, the EuroMayDay, the 15$\mathrm{M}$ Movement or the Indignados. The recent academic focus on migrants, their struggles to find a job and adopt to living conditions in host countries (Fihel and Górny 2013; Górny 2017; Smets 2017), gives another boost to diverse research projects conducted within the frame of precariousness. However, relatively few studies have addressed the fundamental questions concerning the meaning of this concept, its semantic boundaries and changing contextualisation (Waite 2009). Precariousness becomes part of the "noquestions-asked canon" (Bauman 1998) with multiple representations in a real world. As Bauman (1998) points out, "All vogue words tend to share a similar fate: the more experiences they pretend to make transparent, the more they themselves become opaque" (p. 1). Indeed, the operationalisation of this concept is no simple task due to multiple theoretical proposals behind precarious work.

Rodgers and Rodgers (1989) built their theoretical proposal on "atypical" or "nonstandard" forms of work. By "atypical" work, Rodgers understand "various forms of disguised or illegal wage employment, homeworking and moonlighting, selfemployment and outworking" (p. 1). But not all forms of "atypical" work are precarious. In order to distinguish between precarious and non-precarious forms of work, they proposed four dimensions of precariousness: (i) temporal (continuity of employment), (ii) organisational (working conditions), (iii) economic (wages and payment) and (iv) social (working practices and social protection). The Rodgers proposal has been adopted in large-scale comparative studies of labour market in Europe (e.g. European Commission 2004) and in many smaller research projects. The main contribution of the Rodgers study is identification of critical dimensions that could be used in precarious employment-related research.

However, those dimensions sometimes are not easily translated into variables and their indicators. Much depends on the quality of labour market, sector of the economy, particular job etc. For example, on the stable and flexible labour market, the temporal dimension may not be a significant dimension of the precarious work. Some workers (e.g. IT professionals) may prefer the short-term projects due to higher wages and flexibility. At the same time, the organisational dimension does not matter for employees working from home. Although Rodgers and Rodgers proposal may be hardly translatable into explicit and robust indicators for all four forms of labour-related insecurity among precarious migrants, it is probably one the most useful concepts in the literature on the subject.

In more political terms, Standing (2011) blames globalisation for the rise of the precariat. He suggests that globalisation does not dismantle barriers to the commodification of market forces, but introduces new regulations making labour more flexible and uncertain (flexploitation). As a consequence, national class structures become fragmented and gradually fulfilled by precarious class (class-in-the-making). He points out seven forms of labour-related security that contemporary precarious class lacks: (i) labour market security, (ii) employment security, (iii) job security, (iv) work security, (v) skill reproduction security, (vi) income security and (vii) representation security. 
"Not all those in the precariat would value all seven forms of security, but they fare badly in all respects", he adds (Standing 2011, p. 11). Although Standing's proposal became central for many studies focused on precarious jobs, it is always a subjective decision which dimensions are critical in the operationalisation process.

Definitions of the precariat and precariousness available in the literature on the subject indicate at least two common features: (i) uncertainty and (ii) instability related to the duration of employment, social protection, salaries and benefits, relationships with co-workers and management, career stages, etc. (Düll, 2004; Lewchuk et al. 2008). However, apart from loosely defined uncertainty and instability, there are no constitutive features of precarious employment - that is conditions that need to be met for the application of the precariousness framework. Anderson (2010) warns that precariousness can become a "catch-all", that is a concept "meaning everything and nothing at the same time" (p. 303). Empirical studies usually approach this phenomenon from the objective (macro) or/and subjective (micro) point of view. The first stream of research uses macro-indicators (e.g. economic or social) of precariousness, such as share of fixed-term contracts, membership in trade unions and salaries (Goldring and Landolt 2011; Munck 2013). The objective approach rather fits in quantitative research, e.g. survey or desk research. Yet, macro-indicators point at objective changes taking place in social, economic or political dimensions and do not offer insight into individual (or group) strategies of avoidance or adaptation to precarious conditions. On the other hand, the subjective approach analyses precariousness from an individual or group perspective (Duck 2012). This stream of research often relies on the use of in-depth interviews, focus group interviews or ethnographic methods. The subjective approach appears to be useful when there are new factors or dimensions considered as precarious that cannot be measured quantitatively. Moreover, such an approach offers a chance to improve the existing concepts of precariousness by introducing new details diagnosed at the individual level.

Although our in-depth interviews with Ukrainians from the recent wave of migration to Poland fall into the micro category, some macro-indicators helped us to recognise the scale and potential dimensions of precariousness among migrants.

\section{Europe and the Structural Need for Migrations}

Since contemporary Europe depends on different types of migrant labour (both highand low-skilled), in recent years, some restrictive policies against migration have been significantly relaxed. Two macro-trends intensify contemporary migration flows in Europe. The first one is related to the changing demographic situation in the EU countries. Falling fertility rates and ageing led to the decline of population in 2015, and, consequently, to the rising shortage of labour force on the market (Batsaikhan et al. 2018). Although the decline has been reversed by a higher birth rate in 2016 and a massive influx of refugees, shortages on the labour market have further increased.

The second trend stems from regional economic recovery after the global financial crisis and from rapid economic growth in Central and Eastern Europe. As a consequence, many European companies - especially in such sectors as agriculture, tourism, health or IT-become increasingly more affected by shortages of labour force. Eurostat estimates that $2.1 \%$ of jobs in the eurozone and $2.2 \%$ of jobs in the EU countries were 
vacant in the first quarter of 2018 (Eurostat 2018). Such data confirms that the influx of migrants and refugees after 2015 did not fulfil the demand on the European labour market. The simultaneous impact of two macro-economic trends mentioned above increases Europe's dependence on external migrations and reveals weaknesses of European economy. At the same time, this data may suggest that political approval to recent waves of migration was primarily driven by the situation on the European labour market.

\section{Ukrainians in Poland}

Scholars notice a significant transformation in Central and Eastern Europe $(\mathrm{CEE})^{1}$ in terms of migratory patterns (Grzymała-Kazłowska 2013; Grabowska-Lusińska et al. 2011). The economic development and prosperity of recent years has been an important factor behind the transformation of CEE countries from migrant-sending to migrantreceiving states. Falling unemployment rates, decreasing Gini index, growing salaries and a relatively high GDP in CEE countries which belong to the European Union attract foreigners to work and settle in Central and Eastern Europe. Such a prospect becomes particularly attractive to Ukrainians suffering from socioeconomic consequences of the ongoing Russian-Ukrainian conflict in Donetsk and Luhansk oblasts. Cultural and language similarities coupled with geographical proximity make countries such as Poland, Slovakia, Hungary, Lithuania and the Czech Republic the first choice for individuals leaving Ukraine.

In 2017, the European Commission lifted visa requirements for Ukrainians, which enabled them to travel freely to the Schengen area. Based on this change, the Polish government signed an agreement with Ukraine on temporary work registration and long-term work permits for Ukrainians interested in working in Poland. Since there is no dedicated body monitoring migration to Poland, it is difficult to provide adequate estimates of the number of Ukrainians who decide to move across the border. By the end of 2017, there were nearly one million work permits (temporary or long-term) issued for Ukrainian citizens (Chmielewska et al. 2017). However, this number does not include all employees registered before 2017 and those working without any formal authorisation. Some experts estimate that there might be even three million Ukrainians working in Poland and this number is gradually increasing (Lis, 2017). According to various sources, Ukrainians usually take low-paid jobs in sectors such as agriculture, construction and domestic service (Brunarska et al. 2016; Chmielewska et al. 2017). However, this situation changes with the growing demand on Polish labour market for professionals in finance or IT.

One of the most comprehensive sources on the influx of Ukrainians to Poland is probably the report of the National Bank of Poland (Chmielewska et al. 2016) published in 2016 (based on research conducted in 2015). Migrations from Ukraine are divided there into two waves: (i) before 2014 and (ii) after 2014. As established, the recent wave is dominated by young $(18-25 ; 38.8 \%)$ males $(57.9 \%)$, leaving Ukraine for economic reasons $(79.9 \%)$. Moreover, many Ukrainians decide to enrol in Polish

\footnotetext{
${ }^{1}$ Organization for Economic Cooperation and Development (OECD) includes the following countries to Central and Eastern Europe region: Albania, Bulgaria, Croatia, the Czech Republic, Estonia, Hungary, Latvia, Lithuania, Poland, Romania, the Slovak Republic and Slovenia.
} 
universities in order to improve their skills and qualifications. This trend seems to be important for further analysis included in this paper. Comparison between these two waves also shows that many of the recent migrants from Ukraine come from the east of the country, suffering from the Russian-Ukrainian conflict. The recent wave of migration from Ukraine has an enormous impact on the local labour market in Poland and it needs to be emphasised that many different problems related to adaptation and integration of Ukrainians may appear in the local public agendas.

\section{Method}

\section{Data Collection}

Following Rodgers and Rodgers' (1989) proposal, we decided to analyse the recent wave of Ukrainian migration using the precariousness framework. Previous research confirmed that migrants are often condemned to taking low-paying jobs that are below their qualifications, live in poor conditions which make it difficult for their family to join them, have no or very little chance to be promoted and are exposed to various risks in the workplace and their area of residence (Campbell 2013; Lewis et al. 2015; Sumption 2009; Ünlü Ince et al. 2014). Consequently, we prepared a semi-structured scenario with a set of questions related to different aspects of migration with strong emphasis on work, workplace and living conditions. The main part of the interview scenario was designed to match the four dimensions of precarious work: temporal, organisational, economic and social (Rodgers and Rodgers 1989). The temporal dimension was initially referred to the control over continuity of employment and fear of dismissal. The organisational insecurity was reconstructed from working conditions, e.g. work shifts, safety regulations and technology usage. The economic dimensions were primarily paired with payment but we also considered non-financial incentives such as trainings, vouchers and flexible scheduling. The social dimensions were matched with a working atmosphere in general and attitudes towards migrants in particular.

However, the interviewees were also encouraged to talk openly about different aspects of their migrant life. The aim was to collect as much material as possible in order to identify the features, tendencies, social relations and cultural and structural factors which influence the working conditions of Ukrainians employed in Poland. Considering that most of Ukrainian workers have a more or less legal status (often with work permits), we did adjust our research tool in order to avoid problems identified in some previous research with "undocumented immigrants" (Cornelius, 1982). Firstly, we conducted two pilot interviews in order to assess the applicability of the scenario in terms of its openness (structured vs. unstructured), and to identify sensitive and annoying issues which could have a negative impact on the course of the interview. We found that the interviewees are open-minded and talk freely about many, sometimes marginal, issues. Those interviews were conducted in Polish, which unfortunately generated some communication and translation problems. As a result, a semistructured scenario which fitted the research problem, and did not include any questions related to history or politics, was evaluated as the final tool. 
In the next step, we interviewed fifteen Ukrainian workers employed in two warehouses in central Poland. The structure of our sample was very imbalanced in terms of the sex of the interviewees (12 men and 3 women), which stemmed from the fact that warehouses in Poland tend to employ men rather than women. In this round, all interviews were assisted by a professional translator. Based on experience gained from the pilot interviews, we wanted to avoid problems related to the understanding of our scenario. The interviewees were encouraged to speak the language they prefer (Ukrainian or Polish). Most of the interviews had a mixed-Polish-Ukrainian — structure, although many respondents decided to talk in Polish. Before the analytical phase, the material collected in the Ukrainian language was translated into Polish.

\section{Data Analysis}

Drawing on the research methods and techniques applied in prior research focused on migrants (Drinkwater et al. 2009; Fihel and Górny 2013; Luthra et al. 2014), we proposed a three-step analytical procedure aiming to explore qualitative data collected from individual interviews. Although in-depth interviews were conducted in line with the proposed precarity framework, we decided to analyse collected material using some elements of grounded theory approach (Corbin and Strauss 1990; Glaser and Strauss 1967). Many interviews went far beyond our analytical framework; therefore, the goal was to effectively use and classify all collected materials.

In the first step, two researchers independently assigned codes to the data according to the open coding procedure. There was no quantitative restriction at this stage and more than 100 codes in total were identified by both coders. Then, all the codes were compared, discussed and evaluated. As a result only 67 of them were considered important. The next round of coding helped to (re)match textual data to the codes and identify broader themes related to the main problem of the study. In the following step, the initial concepts derived from the identified codes were listed and discussed with a researcher who was not engaged in the project. Based on his comments, some concepts were merged into broader themes referring to precarity among Ukrainian workers in Poland. Themes identified from codes and concepts helped us to understand specific issues related to the dimensions of precarity in focus of the study.

In order to code our interviews, we used the RQDA package (R programming) designed for advanced analysis of textual data (Huang 2018).

\section{Results}

The interviews revealed that precariousness of Ukrainian workers in Poland is a complex phenomenon which is difficult to identify among migrants legally employed in the host country. Unlike many Poles, they do not explicitly share their concerns and discontent about their job. However, more in-depth conversation revealed some interesting problems that may indicate precariousness of Ukrainian workers employed in Polish warehouses. In order to focus on peculiarities related to precariousness of Ukrainian workers in Poland, in the this section, we present two aspects of the research problem: (a) apparent contentment and (b) hidden precarity. These sections follow the course of interviews with Ukrainians employed in Polish warehouses. 


\section{Apparent Contentment}

We found the introduction phase of the interviews really surprising. It turned out that Ukrainian workers in Poland tend to be satisfied with their new working environment, which seemed to indicate that it is not characterised by the four dimensions of precariousness distinguished by Rodgers and Rodgers (1989).

Interviewee 1:

I thought it was going to be much worse but I like this job. The working conditions in Ukraine are much worse than here.

They are not worried about their future prospects on the Polish labour market, which may suggest that their current situation does not answer the description of precariousness in terms of temporal dimension. In general, Ukrainian migrants are very optimistic about their future work and their skills.

Interviewee 2:

I've heard Poland needs Ukrainian workers. Ukrainians are more hard-working than Poles.

Also, most of them stated that they had at least some control over daily work (organisational dimension) and had a chance to introduce different improvements. Polish management was perceived as rather flexible and supportive. In comparison with Ukraine, the Polish working environment is not built around strict, personal control.

Interviewee 3:

There is no pressure here. I have a great team and Poles are wonderful. (...) My employer demands exactly the same from Ukrainian and Polish workers.

However, it needs to be stressed that warehouse jobs do not give many chances for improvements and control of employees over their work is rather minimal.

The social dimension, understood here as the trade union presence and regulations protecting the rights of employees, appears to be more problematic as many interviewees were not aware of the Polish labour law. They have limited opportunities to get familiar with specific regulations due to the language barrier and they do not join trade unions because of the intermediary model of employment (work agency). However, when comparing their current situation in Poland to the Ukrainian environment, they are rather happy and do not perceive themselves as vulnerable to different forms of social abuse. Still, based on that, it cannot be simply assumed that precariousness in terms of its social dimension is not the case here at all.

Only those who moved down their career ladder were much more critical about the warehouse jobs. One of the interviewees was a woman in her fifties with a long experience in office jobs in Ukraine; her partner found her a job in a Polish warehouse. She was shocked: 
Interviewee 1:

I joined my sweetheart; he had been working in Poland for two years. I decided to change my life. I quit my job in Ukraine; my son is a self-supporting adult. (...) My first job was in a warehouse; it was organized by a work agency. I worked off my visa fees, I worked very hard but my relationship with my partner died because of terrible working conditions; love was gone. (...) I had used to worked in an office before, so I was shocked when my sweetheart offered me a job in a warehouse.

When she left her partner and found a new job in another warehouse, her view was very different:

Interviewee 1 .

This job is great. There is no strict control of our work. This job is good, I know 'cause I can compare it to my previous warehouse.

Do our findings suggest that warehouses in Poland offer satisfying working environment for Ukrainians who arrived in the recent wave of migration? Is the difference between Poland and Ukraine so great that critical voices fade away? This is only a partial picture of more complicated phenomena diagnosed in the interviews. We believe that a direct comparison with the working conditions they had experienced in Ukraine enhanced a sense satisfaction and happiness among the interviewees.

\section{Hidden Precariousness}

In 2013, Carole Cadwalladr, The Guardian's journalist, spent a week in a giant warehouse in the UK (Cadwalladr 2013). She reported a lot of maltreatment, e.g. long shifts, minimum wage, sacking and temporary contracts, typical for those trapped in precarious employment. Thus, working in a warehouse is supposed to be hard and exhaustive. We therefore decided to talk about the jobs of our informants in a different manner, without putting stress on their assessment of their current working environment, living conditions, social relations, etc. When conversations warmed up and the interviewees started to trust us more, we heard a lot of interesting comments.

Some of them suggested that Polish employers treat Ukrainians as cheap labour. Interviewee 4:

We are cheap labour here. (...) The difference in salaries between Poland and Ukraine is huge and that is why we accept it.

Considering that the influx of Ukrainian migrants in the last few years reached high levels, such an opinion should not be surprising. What appears to be important is that some labourers from Ukraine are aware of low wages offered in Polish warehouses. At the same time, they are not worried about their future on the Polish labour market due to a large number of job offers. Although this may suggest that there are plenty of jobs available, these are not dream positions. Such jobs allow Ukrainian migrants to survive but they do not exclude the processes of precarity. 
Moreover, many respondents mentioned a temporary character of their staying in Poland. They consider relocating to Germany or other EU countries in near future. Interviewee 5:

We'll stay here only for a year and then we will probably move to Germany. We will learn the language when we get there.

Such plans may indicate that the labour market and/or the quality of life is not satisfying enough and they are not anchored in Poland in terms of stability and security (Grzymała-Kazłowska, 2017). Moreover, this indicates that precariousness among Ukrainian workers in Poland may be the case with regard to the temporal dimension.

Importantly, only a few interviewees pointed out the economic dimension as problematic.

Interviewee 6:

It's a clean place, amazing toilets, good attitude to employees, nice management, but the salary is not good.

This is a strong indication confirming that precariousness is not an abstract idea but a real problem affecting Ukrainians in Poland. Considering the level of salaries in Western European countries, it is hardly surprising that the economic dimension of precariousness is recorded in a country with one of the lowest levels of salaries among European Union states. Even if only two respondents were partly unhappy about their salaries, it clearly draws our attention to this aspect as a strong determinant of the precarious class. Thus, the economic problems mentioned by Rodgers and Rodgers (1989) appear to be a persistent factor contributing to precariousness of migrants. However, it needs to be mentioned that in spite of recent positive changes on the labour market, even Poles complain about low salaries.

Despite favourable comments quoted above, some interviewees pointed at organisational settings as a factor of precariousness:

Interviewee 7:

One day, the electricity got broken and the lights were gone. They switched on alternative lights but the room was quite dark. We continued our work but it was very dangerous because we couldn't see everything around very well. There are many forklifts around so it was a miracle that there was no accident.

Such examples confirm precariousness among Ukrainian migrants in Poland in terms of the organisational dimension. Although in this case there were also Polish employees involved, it needs to be considered that the team including a number of migrants was less prepared to engage in a potential protest.

Some interviewees also pointed out different problems related to contract and labour rights.

Our question:

Did you negotiate your contract? 
Interviewee 8:

First they said we can negotiate it but then ready-made contracts appeared and we had to sign them. So, I had no chance to negotiate it.

Some interviewees complained about working hours. There were promised to have overtime work but in fact they work less. It should be considered as the organisational problem (precaring factor) as most of the Ukrainians in our research had the hourly contracts:

Interviewee 9:

They promised me to work about 10 hours a day and have overtime. But I work only 8 hours a day (...) Only Christmas time was busy here and I had a chance to work long shifts including Saturdays and Sundays.

One interviewee has mentioned the unusual working schedule. However, he was not complaining about it.

Interviewee 11:

We get hourly plan for whole month. One day you work 11 hours, next day it could be 6 , and another it could 8 (...) You can claim day off but it needs to be discussed with supervisor earlier.

However, this problem is much more complex than initially assumed. Despite some previous work experience gained in Poland (e.g. two previous jobs), many migrants do not have a basic knowledge of labour law and regulations. Consequently, although they are aware of different risks, they cannot react appropriately. This example only confirms that there are multiple problems faced by Ukrainians in Poland as regards the social dimension of precariousness distinguished by Rodgers and Rodgers (1989).

Thus, as the interviews progressed, we moved from apparent contentment to real problems of precariousness among Ukrainian workers in Poland. All dimensions of precariousness distinguished by Rodgers and Rodgers (1989) appeared in our interviews and the respondents confirmed some of our initial assumptions about the labour market in Poland.

\section{Discussion}

The interviews revealed that Ukrainian workers in Poland may be exposed to different forms of precariousness but they do not explicitly and openly share negative information related to their jobs and living conditions. In the non-migrant context, such problems as difficult relations with management and co-workers, unfair system of promotion, lack of insurance, low salaries or poor accommodation would be definitely considered as factors of precarity. However, for some unknown reasons, Ukrainian workers in Poland avoid difficult topics and conceal negative job experiences. For example, unambiguously bad rules and regulations, poor working conditions or unacceptable behaviours on the labour market are not considered as faulty or even negative. 
It is probable that differences between Polish and Ukrainian labour markets in terms of technology, organisation and salaries stimulate the effects of surprise and enchantment that restrain newcomers from complaining or even from thinking about their new working and living environment in a negative way. As a consequence, even minor problems are overshadowed by the general positive impression. Considering that all interviewees belong to the most recent wave of migration, such effects appear to be ubiquitous and strong.

It is proposed here that latent precariousness could be further explained at the individual level by social comparison theory originally proposed by Festinger (1954). Accordingly, people compare themselves to others in order to self-evaluate, self-motivate or self-enhance. Social comparison is a critical mechanism allowing people to scan their life strategies and current standings and find conclusions for future actions. Social comparisons usually appear when objective information is not available (Festinger 1954). However, there are different reference frames used in social comparison process. Wills (1981) suggests that individuals suffering from negative affect may compare themselves with the less fortunate others in order to self-enhance. "People who are unhappy like to see others who are unhappy", he bluntly explains. Such "downward comparison" appears to be an effective and popular strategy helping many individuals to deal with frustration or failure occurring in different life stages. On the contrary, upward comparison with people perceived as better off in some way may stimulate one to improve. It has been established that upward comparison characterises highly motivated individuals (Wheeler 1966) and may be demoralising for those feeling forced to improve (Wood 1989).

We suggest that downward social comparison helps to explain why some Ukrainians working in Poland avoid discussing negative aspects of their jobs and prefer to focus on the positive side of emigration. The strategy of comparing oneself with less fortunate others - in this case, Ukrainians in Ukraine - may be understood as a popular and comfortable mechanism reducing frustration and/or other negative emotions. Downward comparison reduces cognitive dissonance (Festinger 1964) and helps to selfenhance those trapped in difficult working or living conditions. Such a downward strategy fulfils the therapeutic needs of migrants embedded in the objectively difficult situation. Although both patterns of comparison were identified during the interviews, downward mechanism seems to be crucial for understanding the latent precariousness phenomena among Ukrainians working in Poland. As mentioned above, downward comparison appears to be stronger in the early phase of migration. Thus, it is necessary to adjust the research scenario to the phase of migration describing the respondents.

Moreover, the comparison process, upward or downward, depends on multiple abilities and dispositions of the individual (Gibbons and Buunk 1999). People unaware of differences may not be encouraged to compare with others in order to self-evaluate, self-motivate or self-enhance. Accordingly, less-educated migrants with poor access to information about the labour market in the host country may accept their precarious working environment due to the absence of social comparisons. The interviews indicated that the local legal and regulatory framework tends to be ignored by Ukrainians working in Poland. Most of our interviewees suffered from serious deficiencies in the area of labour market regulations (e.g. social security, employer's obligations). Thus, without such basic knowledge, it is rather impossible to judge which actions and 
demands of the employers are legal and which are not. At the same time, it is difficult to recognise which labour conditions may have precarious character.

What all interviews reveal is that precariousness is a concept adjusted to the more economically developed countries and therefore difficult to apply in Central and Eastern Europe. After the fall of communism, CEE countries suffered from the longterm instability on the labour market, what brought a specific job-related experience. Uncertainty or instability with reference to working and living conditions may be differently understood by researchers, members of the host society and migrants, all of them representing diverse social contexts and different cultures. For example, precariousness defined from the host society's point of view may be translated into a set of unique life chances by migrants. Moreover, researchers embedded in the more developed economies may identify precariousness in the less-developed countries in which local customs and traditions regulate the labour markets. While such a strategy may bring some interesting results and contribute to the literature on the subject, at the same time, it appears to be somewhat far-fetched. Thus, although matching those three perspectives (researcher, host society, migrants) is not easy, it is necessary for successful qualitative and quantitative research.

\section{Limitations and Future Research}

As mentioned above, we encountered some difficulties while translating the idea of precariousness into the interview scenario. Due to economic, cultural and political differences between contemporary Polish and Ukrainian labour markets, it was a challenging task to select areas in which precariousness of migrants may appear. Various perceptions of the host society and diverse expectations from the Polish labour market may suggest that there is no single set of indicators of precariousness among migrants. Moreover, precariousness of Ukrainian migrants is a hidden phenomenon that needs to be discovered as the interview proceeds. Thus, future research should build an interview scenario adjusted to the manifest and the latent dimensions of precariousness among migrants. As shown above, in the case of Ukrainian migrants in Poland, the latent ones may be completely different from those manifest.

Due to various limitations, our research project focused on migrants employed in warehouses. Although Cadwalladr (2013) discussed many factors of precarity in contemporary warehouses, this phenomenon cannot be limited to this environment. As it is today, different forms of precariousness can also be found in the most dynamic sectors of the modern economy (e.g. IT or finance). Future projects should therefore pay attention to various sectors in order to find specific determinants of precariousness among migrant workers. Moreover, it is reasonable to conduct simultaneous research in more than one host country. The picture of migrants built upon material collected in different socio-cultural environments could cast a new light on popular concepts of precariousness discussed in the literature on the subject.

Finally, future research analysing precariousness among migrants in different sociocultural environments needs to evaluate in detail the living conditions of migrant workers. Our study confirmed that migrants often try to save as much as possible on accommodation. Importantly, difficult living conditions may indicate strategies of compensation for relatively lower salaries. Such compensation may not be noticed by 
researchers strictly focused on the labour market. Therefore, studies exploring multiple dimensions of migration, sometimes indirectly connected with the labour market, may bring valuable findings highlighting complex relations between living and working strategies.

\section{Conclusion}

Ukrainian migrants arriving in Poland in the recent wave of migration are exposed to different forms of precariousness distinguished by Rodgers and Rodgers (1989). However, it is difficult to find solid evidence confirming hypotheses suggesting uncertainty and instability with regard to the working conditions of migrants who are legally employed in Poland. As proposed above, it is because many migrants compare (if at all) their current situation with difficult working and living conditions in Ukraine. As a consequence, they usually resort to "downward comparison" in order to deal with frustration or failure often encountered in the new environment. Thus, it is necessary to construct a dynamic interview scenario adjusted to the Eastern European perception of labour market and housing. Last, but not least, building a trusting relationship over the interview appears to be a critical precondition of research conducted within the precarious research frame.

Open Access This article is distributed under the terms of the Creative Commons Attribution 4.0 International License (http://creativecommons.org/licenses/by/4.0/), which permits unrestricted use, distribution, and reproduction in any medium, provided you give appropriate credit to the original author(s) and the source, provide a link to the Creative Commons license, and indicate if changes were made.

\section{References}

Anderson, B. (2010). Migration, immigration controls and the fashioning of precarious workers. Work, Employment and Society, 24(2), 300. https://doi.org/10.1177/0950017010362141.

Arrowood, J. A., \& Friend, R. (1969). Other factors determining choice of a comparison other. Journal of Experimental Social Psychology, 5(2), 233-239. https://doi.org/10.1016/0022-1031(69)90048-1.

Batsaikhan, U., Darvas, Z., \& Raposo, G. I. (2018). Migration and mobility in the European Union. Bruegel Blueprint Studies., 39, 1037-1038. https://doi.org/10.1080/1369183X.2013.772789.

Bauman, Z. (1998). Globalization: the human consequences. (Polity, Ed.) (First). Cambridge, Oxford. https://doi.org/10.1016/S0962-6298(00)00045-7.

Brunarska, Z., Kindler, M., Szulecka, M., \& Toru, S. (2016). Ukrainian migration to Poland: a "local" mobility? In O. Fedyuk \& M. Kindler (Eds.), Ukrainian migration to the European Union (pp. 115131). Cham: Springer. https://doi.org/10.1007/978-3-319-41776-9.

Cadwalladr, C. (2013). My week as an Amazon insider, “the Guardian”, 1 December, [Accessed: 21.09.2018] https://www.theguardian.com/technology/2013/dec/01/week-amazon-insider-feature-treatmentemployees-work

Campbell, S. (2013). Workplace struggles of precarious migrants in Thailand. Global Labour Journal, 4(2), $134-151$.

Carling, J. (2002). Migration in the age of involuntary immobility: theoretical reflections and Cape Verdean experiences. Journal of Ethnic and Migration Studies, 28(1), 5-42. https://doi.org/10.1080 $/ 13691830120103912$.

Carling, J., \& Collins, F. (2018). Aspiration, desire and drivers of migration. Journal of Ethnic and Migration Studies, 44(6), 909-926. https://doi.org/10.1080/1369183X.2017.1384134. 
Carling, J., \& Schewel, K. (2018). Revisiting aspiration and ability in international migration. Journal of Ethnic and Migration Studies, 44(6), 945-963. https://doi.org/10.1080/1369183X.2017.1384146.

Castells, M. (2000). The rise of the network society (second). Malden, Oxford, Carlton: Blackwell Publishing Ltd..

Chmielewska, I., Dobroczek, G., \& Puzynkiewicz, J. (2016). Obywatele Ukrainy pracujący w Polsce - raport $\mathrm{z}$ badania.

Chmielewska, I., Dobroczek, G., \& Puzynkiewicz, J. (2017). Obywatele Ukrainy pracujący w Polsce - raport $\mathrm{z}$ badania.

Corbin, J., \& Strauss, A. (1990). Grounded theory research: procedures, canons and evaluative criteria. Qualitative Sociology, 13(1), 3-21. https://doi.org/10.1007/BF00988593.

Cornelius, W. A. (2018) Interviewing Undocumented Immigrants: Methodological Reflections Based on Fieldwork in Mexico and the U. S.. International Migration Review 16 (2):378-411

Czaika, M., \& Parsons, C. R. (2017). The gravity of high-skilled migration policies. Demography, 54(2), 603630. https://doi.org/10.1007/s13524-017-0559-1.

Drinkwater, S., Eade, J., \& Garapich, M. (2009). Poles apart? EU enlargement and the labour market outcomes of immigrants in the United Kingdom. International Migration, 47(1), 161-190. https://doi.org/10.1111 j.1468-2435.2008.00500.x.

Duck, W. O. (2012). An ethnographic portrait of a precarious life: getting by on even less. The Annals of the American Academy of Political and Social Science, 642(1), 124-138. https://doi.org/10.1177 /0002716212438202.

Düll, N. (2004). Defining and assessing precarious employment in Europe: a review of main studies and surveys. Munich: ESOPE Project.

European Commission. (2004). Precarious employment in Europe: a comparative study of labour market related.

European Migration Network. (2007). Conditions of entry and residence of third country highly-skilled workers in the EU. European Commission.

Eurostat. (2018). Job vacancy statistics.

Festinger, L. (1954). A theory of social comparison processes. Human Relations, VII(2), 117-140.

Festinger, L. (1964). Conflict, decision and dissonance (Vol. 6, p. 544). Stanford: Stanford University Press. https://doi.org/10.2307/3318996.

Fihel, A., \& Górny, A. (2013). To settle or to leave again? Patterns of return migration to Poland during the transition period. Central and Eastern European Migration Review, 2(1), 55-76.

Gibbons, F. X. \& Buunk, B. P. (1999). Individual differences in social comparison: development of a scale of social comparison orientation, 76(1), 129-142.

Glaser, B. G., \& Strauss, A. L. (1967). The discovery of grounded theory: strategies for qualitative research. In AldineTransaction (Ed.), Observations (Vol. Vol. 1). London: New Brunswick. https://doi.org/10.2307 12575405 .

Goldring, L., \& Landolt, P. (2011). Caught in the work-citizenship matrix: the lasting effects of precarious legal status on work for Toronto immigrants. Globalizations, 8(3), 325-341. https://doi.org/10.1080 /14747731.2011.576850.

Górny, A. (2017). All circular but different: variation in patterns of Ukraine-to-Poland migration. Population, Space and Place, 23(8), 1-10. https://doi.org/10.1002/psp.2074.

Grabowska-Lusińska, I., Drbohlav, D., \& Hars, A. (Eds.). (2011). Immigration puzzles: comparative analysis of the Czech Republic. Hungary and Poland before and after joining the EU: Lambert Academic Publishing.

Grzymała-Kazłowska, A. (2013). Migration and socio-demographic processes in Central and Eastern Europe: Characteristics, specificity and internal differences. Central and Eastern European Migration Review, 2(Iglicka 2001), 5-11.

Grzymała-Kazłowska, A. (2017) From connecting to social anchoring: adaptation and 'settlement' of Polish migrants in the UK. Journal of Ethnic and Migration Studies 44 (2):252-269

Hewison, K., \& Kalleberg, A. L. (2013). Precarious work and flexibilization in South and Southeast Asia. American Behavioral Scientist, 57(4), 395-402. https://doi.org/10.1177/0002764212466235.

Huang, R. (2018). RQDA: R-based qualitative data analysis. R package version 0.3-1. URL http://rqda.rforge.r-project.org.

Lewchuk, W., Clarke, M., \& De Wolff, A. (2008). Working without commitments: precarious employment and health. Work, Employment and Society, 22(3), 387-406. https://doi.org/10.1177/0950017008093477.

Lewis, H., Dwyer, P., Hodkinson, S., \& Waite, L. (2015). Hyper-precarious lives: migrants, work and forced labour in the Global North. Progress in Human Geography, 39(5), 580-600. https://doi.org/10.1177 $/ 0309132514548303$. 
Lis, M. (2017). Za rok w Polsce będzie pracować 3 mln Ukraińców. Ich pensje rosną szybciej niż przeciętne, "Money.pl". https:/www.money.pl/gospodarka/unia-europejska/wiadomosci/artykul/ukraincy-pracujacyw-polsce-pensja-liczba,118,0,2381430.html. Accessed 10/07/2018.

Luthra, R. R., Platt, L., \& Salamonska, J. (2014). Migrant diversity, migration motivations and early integration: the case of Poles in Germany, the Netherlands, London and Dublin. LEQS Paper. https://doi.org/10.2139/ssrn.2428284.

Missirian, A., \& Schlenker, W. (2017). Asylum applications respond to temperature fluctuations. Science, 358(6370), 1610-1614. https://doi.org/10.1126/science.aao0432.

Munck, R. (2013). The precariat: a view from the south. Third World Quarterly, 34(5), 747-762. https://doi. org/10.1080/01436597.2013.800751.

Neilson, B. \& Rossiter, N. (2009). Precarity as a political concept new forms of connection, 1-11.

Rodgers, G. \& Rodgers, J. (1989). Precarious jobs in labour market regulation: the growth of atypical employment in Western Europe.

Smets, K. (2017). The way Syrian refugees in Turkey use media: understanding "connected refugees" through a non-media-centric and local approach. Communications., 43, 113-123. https://doi.org/10.1515 /commun-2017-0041.

Standing, G. (2011). The precariat: the new dangerous class. London, New York: BLOOMSBURY ACADEMIC. https://doi.org/10.1177/1536504214558209.

Sumption, M. (2009). Social networks and Polish immigration to the UK. Economics of Migration Working Paper (Vol. 5). Retrieved from http://ethnopedia.org.uk/resources/social_networks_polish_immigration. pdf

Ünlü Ince, B., Cuijpers, P., van’t Hof, E., \& Riper, H. (2014). Reaching and recruiting Turkish migrants for a clinical trial through Facebook: a process evaluation. Internet Interventions, 1(2), 74-83. https://doi. org/10.1016/j.invent.2014.05.003.

Waite, L. (2009). A place and space for a critical geography of precarity? Geography Compass, 3(1), 412-433. https://doi.org/10.1111/j.1749-8198.2008.00184.x.

Wheeler, L. (1966). Motivation as a determinant of upward comparison. Journal of Experimental Social Psychology, 1(SUPPL. 1), 27-31. https://doi.org/10.1016/0022-1031(66)90062-X.

Wills, T. A. (1981). Downward social comparison principles in social psychology. Psychological Bulletin, 90(2), 245-271.

Wood, J. V. (1989). Theory and research concerning social comparisons of personal attributes. Psychological Bulletin, 106(2), 231-248. https://doi.org/10.1037/0033-2909.106.2.231.

Publisher's Note Springer Nature remains neutral with regard to jurisdictional claims in published maps and institutional affiliations. 